\title{
Outcomes of stage IIB osteosarcoma treated by limb salvage surgery using extracorporeally irradiated (ECI) autograft
}

\author{
Achmad F. Kamal, ${ }^{1}$ Ismail, ${ }^{1}$ Faisal Mi'raj,, ${ }^{2}$ Errol U. Hutagalung ${ }^{1}$ \\ ${ }^{1}$ Department of Orthopaedics, Faculty of Medicine, University of Indonesia / Dr. Cipto Mangunkusumo General National \\ Hospital, Jakarta, Indonesia \\ ${ }^{2}$ Department of Orthopaedics, Fatmawati Hospital, Jakarta, Indonesia
}

\begin{abstract}
Abstrak
Latar belakang: Teknik radiasi ekstrakorporeal merupakan alternatif tindakan pembedahan penyelamatan ekstremitas pada kasus osteosarkoma khususnya di pusat layanan dengan keterbatasan endoprostesis dan alograf. Penelitian ini bertujuan untuk mengevaluasi hasil tindakan pembedahan penyelamatan ekstremitas dengan otograf yang diradiasi secara ekstrakorporeal pada pasien-pasien osteosarkoma yang datang ke RSCM.
\end{abstract}

Metode: Studi ini menggunakan desain kohort retrospektif yang dilakukan pada 20 pasien osteosarkoma stadium IIB yang diterapi dengan pembedahan penyelamatan ekstremitas dengan otograf yang diradiasi secara ektrakorporeal selama periode 1995-2008. Dilakukan evaluasi terhadap angka kesintasan, rekurensi lokal, metastasis, komplikasi, lamanya unifikasi, dan skor fungsional menurut sistem skor Musculoskeletal Tumor Society Scoring System (MSTS). Metode Kaplan-Meier digunakan untuk mendeskripsikan kesintasan, angka rekurensi lokal, kesintasan bebas tumor, dan kesintasan bebas metastasis. Hubungan variabel-variabel seperti usia, jenis kelamin, lokasi tumor, ukuran tumor, tipe osteosarkoma, kadar alkali fosfatase serum, jenis biopsi, dan klasifikasi Huvos dianalisis dengan uji log rank. Uji chi-square digunakan untuk menganalisis hubungan antara skor MSTS dan karakteristik pasien, angka rekurensi, metastasis, serta komplikasi.

Hasil: Kesintasan 5 tahun 54,97 \pm 9,8\%, kesintasan bebas rekurensi lokal 5 tahun 66,5 \pm 7,6\%, dan kesintasan bebas metastasis 5 tahun 57,13 \pm 10,04\%. Enam pasien meninggal dunia, lima disebabkan oleh metastasis ke paru dan satu karena toksisitas kemoterapi. Tiga pasien menjalani konversi amputasi karena rekurensi lokal. Kurva Kaplan-Meier menunjukkan Huvos (III,IV) selalu memberikan angka kesintasan, kesintasan bebas rekurensi lokal, dan kesintasan bebas metastasis yang lebih baik daripada Huvos (I, II). Kadar alkali fosfatase serum yang normal selalu memberikan kesintasan bebas rekurensi lokal yang lebih baik dibandingkan dengan kadar alkali fosfatase serum yang meningkat. Angka unifikasi rata-rata 8,13 bulan. Skor MSTS dengan hasil baik (70,63\%) dijumpai pada pasien yang bebas osteosarkoma pasca terapi, tetapi skor MSTS dengan hasil buruk dijumpai pada pasien dengan rekurensi lokal $(p=0,025)$, metastasis $(p=0,01)$, pasien dengan komplikasi $(p=0,03)$, dan kombinasi ketiganya $(p=0,001)$.

Kesimpulan: Luaran fungsional dengan skor MSTS baik (70,63\%) didapatkan pada pasien yang bebas osteosarkoma pasca terapi, skor MSTS buruk dijumpai pada pasien dengan rekurensi lokal, metastasis, pasien dengan komplikasi, dan kombinasi ketiganya. (Med J Indones 2011; 20:131-7)

\begin{abstract}
Background: Extracorporeally irradiated (ECI) technique is an alternative of limb salvage procedure in treating osteosarcoma regarding limitation of endoprosthesis and allograft. This study evaluated the outcomes of limb salvage surgery using extracorporeally irradiated (ECI) autograft and its correlation with patient's characteristics.

Methods: Retrospective cohort design was performed to study 20 patients with stage IIB osteosarcoma treated by ECI autograft from 1995 to 2008. Survival, local recurrence, metastases, complications, union time and functional score based on Musculoskeletal Tumor Society scoring system-(MSTS) were evaluated. Kaplan-Meier method was used to describe survival, local recurrence free survival, and metastases free survival. The correlation among patient's characteristics that were age, gender, duration, site of tumor size, type of osteosarcoma, SAP (serum alkaline phosphatase) level, type of biopsy, and type of Huvos were analyzed by Log rank test. Chi-square test was used to analyze the correlation between MSTS score and patient's characteristics, local recurrence, metastases, complications.

Results: Five-year survival was $54.97 \pm 9.8 \%$, five-year local recurrence free survival was $66.5 \pm 7.6 \%$, and five year metastasis-free survival was $57.13 \pm 10.04 \%$. Six patients died, five were due to lung metastases and one due to complication of chemotherapy. Three underwent amputation after local recurrence. Kaplan-Meier curve showed that a good type of Huvos (III, IV) always gave better survival, local recurrence free survival, and metastases free survival than poor type of Huvos (I,II). Normal SAP level gave better local recurrence free survival compare to increased level of SAP. Mean of union rate was 8.13 months. MSTS mean score was good $(70.63 \%)$ in patients with no evidence of disease. MSTS score was poor in patients with local recurrence $(p=0.025)$, metastases $(p=0.01)$, complications $(p=0.03)$, and the combined of those three outcomes $(p=0.001)$.
\end{abstract}

Conclusions: Functional outcome was poor in patients with local recurrence, metastases, and complications. SAP level and type of Huvos could be studied further as predictive factors for the outcomes (survival, local recurrence, metastases). (Med J Indones 2011; 20:131-7)

Key words: extracorporeally irradiated autograft (ECI), osteosarcoma stage IIB, outcomes 
Primary malignant neoplasms of bone are relatively rare but, of these, osteosarcoma is the most common. ${ }^{1}$ It is also the most common malignancy presented to Cipto Mangunkusumo Hospital. We had 219 cases of osteosarcoma from 1995 to 2008 (16.8 cases/year), and more than $90 \%$ cases came with stage IIB.

Before the 1970s, management routinely consisted of transbone amputations or disarticulations, with survival rates of $10 \%$ to $20 \%{ }^{2}$ The treatment and prognosis of osteosarcoma have changed dramatically since adjuvant chemotherapy began to be used in the early $1970 \mathrm{~s} \cdot{ }^{3-7}$ Radical ablative surgery has been largely abandoned in favour of limb salvage by procedures consisting of en bloc resection of the tumor and reconstruction with a prosthesis, an allograft or a bridging technique, as introduced by Juvara. ${ }^{4}$

Computed tomography and magnetic resonance imaging (MRI) allow the precise visualization of the anatomic location of a tumor and its relation to surrounding structures. ${ }^{2,8}$ Preoperative planning has been advanced through the use of these modalities, fostering better patient selection for specific treatment strategies and lowering the morbidity rates of biopsy and subsequent resection. ${ }^{9}$ Multimodality therapy has increased long-term survival rates of patients with chemotherapy-sensitive tumors from $5 \%$ to $10 \% 20$ years ago to $60 \%$ to $75 \%$ most recently.

Currently, we are able to choose from a variety of methods of reconstruction, including osteoarticular allografts, intercalary allografts, allograft-prosthetic composites, arthrodesis with autogenous or allogenic bone, custom made prostheses, and rotationalplasty., 12-14

Thus, since 1995, we have used an alternative technique, namely en bloc resection of the tumor, extracorporeal irradiation (ECI) and re-implantation of the resected bone. This procedure was first described by Uyttendaele et al. in $1988 .{ }^{15}$ It has several theoretical advantages, including the preservation of the range of movement of a joint, restoration of the normal mass of bone, and avoidance of early and late loosening and breakage of a massive prosthesis. ${ }^{7}{ }^{15}$ It is a very useful procedure regarding limitation of obtaining allograft or endoprosthesis in our center. We now evaluate the outcomes of 20 patients with osteosarcoma stage IIB treated by this procedure during 1995-2008.

\section{METHODS}

We have evaluated the outcomes of 20 stage IIB osteosarcoma patients treated by en bloc resection, ECI and re-implantation of the irradiated bone from 1995 to 2008 .

Patient characteristics are given in Table 1. Survival, local recurrence, metastases, complications, union time and functional score based on Musculoskeletal Tumor Society Scoring System - (MSTS) were evaluated from 1 to 84 months follow up. Survival was measured since patients underwent the operation (ECI) until the time of follow up or death. Local recurrence was defined by physical, radiologic, and histophatologic examination from the time it occurred since the operation. Metastasis was found by chest X-Ray, CT scan thorax, or bone scan. Complications that we observed were infection, fracture, graft resorption, limb shortening and joint instability. Union time was defined with the appearance of bridging callus on the X-ray. Functional status was measured by Musculoskeletal Tumor Society Scoring System (MSTS).

\section{Operative technique}

After en-bloc resection, the segment is wrapped in the wet sterile drapes and sterile plastic bags. The resected segment than placed in a box filled with dry ice. The packet is delivered for irradiation in National Nuclear Institute (BATAN). Meanwhile, the operative site is prepared for re-implantation on the next day. On return the bone segment is removed from the plastic bag and soaked in warm antibiotic solution. Before adding antibiotic, we took sample water where the graft soaked for culture. It is cleared of unnecessary soft tissue leaving important muscle insertions for re-attachment and then re-implanted.

\section{Extracorporeal irradiation}

Irradiation was performed in National Nuclear Institute by $300 \mathrm{~Gy}$ in $-80^{\circ} \mathrm{C}$. Transport and irradiation took more than two hours, during which the remaining bone was prepared for repair. Except for the joint capsule and ligament, the soft tissues and the bulk of the tumor were removed from the heavily irradiated resection specimen, but part of the tumor was always left in place, so that some dead tumor cells would be available to help stimulate the patients' immunological system, if indeed this was relevant. Reimplantation and fixation were performed in the next day. Postoperatively, immobilisation in plaster cast or an orthosis was continued until there was radiographic evidence of bony union. For a tumor in the lower limb, weightbearing was prohibited for approximately one year because of the time needed for the vascularization and remodeling of a massive autograft. This would depend on the size and anatomical location of the graft, but will be at least six months, and may never be complete. Samples of bone taken at reoperation, one year or more later, showed that there was partial replacement by new bone and fresh fibrous tissue but the framework of dead bone was also present. ${ }^{5}$ 
Table 1. Patient characteristics treated by extracorporeally irradiation autograft (ECI)

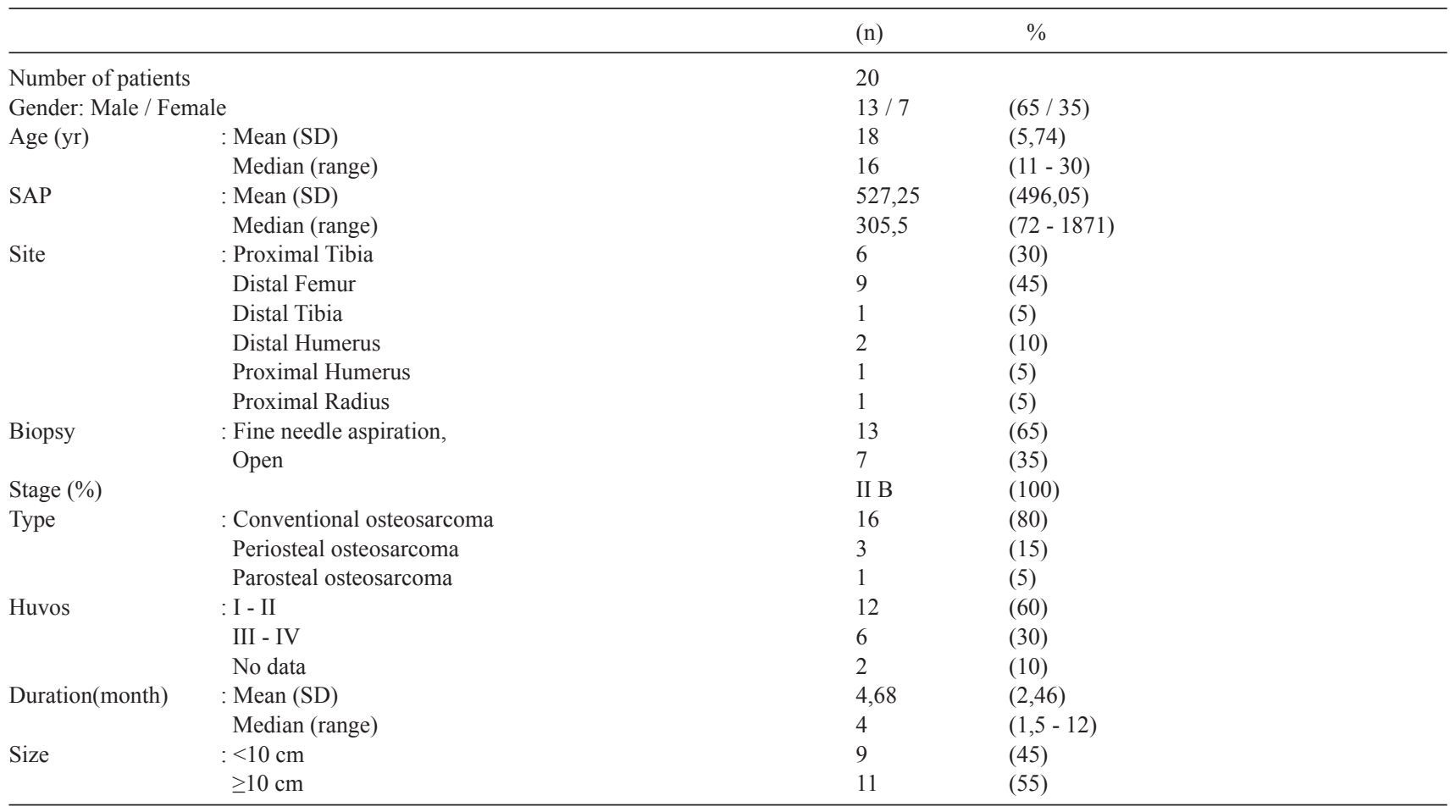

* SAP : serum alkaline phosphatase

\section{Statistics analysis}

Kaplan-Meier method was used to describe survival, local recurrence free survival, metastases free survival. The correlation with patient's characteristics that wereage, gender, duration, site of tumor size, type of osteosarcoma, SAP (serum alkaline phosphatase) level, type of biopsy, and type of Huvos were analyzed by Log rank test. Chi-square test was used to analyze the correlation between MSTS score and patient's characteristics, local recurrence, metastases, complications.

\section{RESULTS}

The mean follow up was 26 months (1 to 84 months) measured from the date of surgery. The results are summarized in Table 2 . Of the 20 patients, 11 patients $(55 \%)$ were free of disease, three patients $(15 \%)$ were loss of follow up and six patients (30\%) died. Five from six patients died due to lung metastases, and one patient died due to complication of chemotherapy.

Five year survival of 20 patients was $54,97 \pm 9,8 \%$ $(95 \%$ CI, 35,72-74,21). There was no significant correlationbetweensurvivaland patients'characteristics, however trend of Kaplan-Meier curve formed by size of the tumor and the Huvos had a constant pattern. It was showed that tumor size more than $10 \mathrm{~cm}$ in diameter always had better survival than tumor size less than 10 $\mathrm{cm}$. Good type of Huvos (III\&IV) always had better survival than poor type of Huvos (I\&II). Survival correlated significantly with metastases $(\mathrm{p}=0,000)$.

\section{Local Recurrence}

Four patients $(20 \%)$ had local recurrence and three of them underwent above knee amputation. One patient also developed lung metastases.

Five years local recurrence free survival was $66.5 \pm$ $7.6 \%$ (95\% CI, 51.6\%-81.7\%). There was significant correlation between local recurrence free survival and tumor size $(\mathrm{p}=0.036)$, but there was no correlation with other patients characteristics $(\mathrm{p}>0.005)$. Curve that formed by SAP and Huvos had constant pattern. It tended to have significant correlation. Increased SAP had higher local recurrence. Poor type of Huvos had higher local recurrence.

\section{Metastases}

Metastases occurred in five patients (25\%), one patient also developed local recurrence. All of them died $(\mathrm{p}=0.000)$. Five year metastasis free survival $57.13 \pm 10.04 \%(95 \%$ CI, $37.45-76.82 \%)$. There was no correlation between metastases and patient's characteristics. However, curves formed by tumor size and type of Huvos showed that they tend to be significantly correlated. Size of more than $10 \mathrm{~cm}$ had higher metastases. Poor type of Huvos had higher metastases. 
Table 2. Outcomes of 20 patients treated by ECI

\begin{tabular}{|c|c|c|c|}
\hline & & (n) & $\%$ \\
\hline \multirow[t]{2}{*}{ Local recurrence } & :Yes & 16 & (80) \\
\hline & No & 4 & (20) \\
\hline \multirow[t]{2}{*}{ Metastases } & :Yes & 15 & (75) \\
\hline & No & 5 & (25) \\
\hline \multirow{9}{*}{ Complication } & : Infection & 5 & \\
\hline & Fracture & 2 & \\
\hline & Knee instability & 8 & \\
\hline & Partial skin necrosis & 1 & \\
\hline & Shortening & 1 & \\
\hline & Bone resorption & 1 & \\
\hline & Leucopeni (chemotherapy associated) & 1 & \\
\hline & No evidence of disease & 9 & \\
\hline & No complication & 4 & \\
\hline \multirow[t]{2}{*}{ Union time } & : Mean $(\mathrm{SD})$ & 8,1 & $(2,78)$ \\
\hline & Median (range) & 8 & $(4-12)$ \\
\hline \multirow[t]{2}{*}{ MSTS (\%) } & : Mean $(\mathrm{SD})$ & 55,1 & $(16,76)$ \\
\hline & Median (range) & 54,95 & $(33,3-76,6)$ \\
\hline \multirow[t]{2}{*}{ Follow up (month) } & : Mean (SD) & 26,9 & $(23,52)$ \\
\hline & Median (range) & 19 & $(1-84)$ \\
\hline
\end{tabular}

*MSTS: Musculoskeletal Tumour Society Score

\section{Complications}

Five patients had infection (25\%); three of them also developed local recurrence, two of them underwent amputation, while one patient refused. Two patients had lung metastases and died, one of them also developed local recurrence. This patient had partial skin necrosis and was locally flapped and died.

Two of five had debridement, one of them had undergone bone transport by Ilizarov method. These two patients could be relieved from infection. One of five had bone resorption and was planned to use an allograft.

Two patients had graft fracture and had undergone revision with graft/cement augmentation. Limb shortening of $2 \mathrm{~cm}$ occured in one patient that had been operated in 12 years of age. Knee instability occurred in all patients with tumor around knee.

Another complications caused by side effect of adjuvant chemotherapy occurred in one patient $(5 \%)$. The patient developed leucopenia and died.

\section{Union Time}

Fifteen of twenty patients had union on the reimplanted segment with union time rate 8.13 months (4-12 months).

\section{MSTS Score}

All patients with no evidence of disease (NED) had good MSTS score rate of $70.63 \%$ (63.3-76.6\%). Six patients with complication had poor MSTS score rate $41.63 \%$ (33.3-46.6\%). Patients with combined complication and local recurrence or metastases had worst MSTS score rate 35.35\% (33.3-46.6\%). Statistically, there was no correlation between MSTS score and patients characteristics $(\mathrm{p}>0.05)$. But there were significant correlation with local recurrence $(p=0.025)$, metastases $(p=0.011)$, complications $(\mathrm{p}=003)$, combined complications + local rccurrence + metastases $(\mathrm{p}=0.0001)$ (Table 3$)$.

Table 3. Analysis of MSTS score

\begin{tabular}{lccc}
\hline \multicolumn{1}{c}{ Outcomes } & MSTS (poor) & MSTS (good) & p \\
\hline Local reccurrence & & 0 & 0,025 \\
Yes & 4 & 10 & \\
No & 6 & 0 & 0,01 \\
Metastases & 5 & 10 & \\
Yes & 5 & 0 & 0,03 \\
No & & 10 & \\
Other Complications & 6 & 0 & 0,00 \\
Yes & 4 & 10 & \\
No & 10 & 0 & \\
Combine all & 0 & & \\
Yes & & & \\
No & & & \\
\hline
\end{tabular}




\section{DISCUSSION}

Nowadays, limb salvage procedure is prefered to amputation. ${ }^{2}$ Neo-adjuvant chemotherapy reduced size of the tumor and, combined with improvement of radiological instruments such as CT scan and MRI, resulted in developing reconstruction technique. Limb salvage was expected to have better function and survival rate than amputation was. ${ }^{2,16}$ Extracorporeal irradiation (ECI) autograft is a usefull alternative of limb salvage procedure regarding limitation of endoprostheses and allograft. Bone stock can be maintained and suitable for the patient and can preserve epiphyseal plate in immature patient. ${ }^{17,18}$

From 1995 to 2008,20 patients with stage IIB osteosarcoma underwent limb salvage procedure by ECI. The outcomes showed similar characteristics with previous studies.

\section{Survival}

Five year survival rate was $54.97 \pm 9.8 \%$. This was similar to those of other studies (40-70\%), and not too different with that of amputation $(68,5 \%) \cdot{ }^{19}$ This survival had no correlation with patient's characteristics. Kaplan Meier curve formed by tumor size and Huvos showed constant pattern. Patients with tumor size $<10 \mathrm{~cm}$ in diameter and good type of Huvos always had better survival than tumor size $>10 \mathrm{~cm}$ in diameter and poor type of Huvos. It could be proven with larger sample of patients. Huvos et al. reported that the survival rate of patients with tumor cell necrosis of more than $90 \%$ following neoadjuvant chemotherapy was $80-90 \%$, and the survival rate of those with cell tumor nerosis of less than $90 \%$ was $15 \%{ }^{20}$ These survival rates showed statistically strong correlation with metastases $(\mathrm{p}=0.0001)$. All patients with lung metastases (4 patients) died. In the previous report, $80-90 \%$ patients with osteosarcoma died, even those who had already undergone ablative procedure. Micrometastases had developed in most cases. $^{21,22}$

\section{Local reccurence}

We had four patients $(20 \%)$ with local recurrence. All of them had tumor size $>10 \mathrm{~cm}$ diameter. In previous studies local recurrence developed in $5-10 \%$ patients that performed marginal excision. ${ }^{23} \mathrm{All}$ of our patients underwent wide excision, but it was probable that not all of them had their tumors adequately excised.

Five-year local recurrence free survival was $66.5 \pm$ $7.6 \%$. There was significant correlation between local recurrence and tumor size $(\mathrm{p}=0.036)$. In other studies, tumor size had become prognostic factor that influence local recurrence. $55 \%$ our patients had tumor size $>$ $10 \mathrm{~cm}$ in diameter. So the result was inferior to that of other studies $(85-90 \%) .{ }^{23}$ This local recurrence free survival had no correlation with other patient's characteristics $(p>0,005)$. The curve formed by SAP and Huvos showed constant pattern. Patients with normal level of SAP and good type of Huvos always had better local recurrence free survival than increased SAP and poor type of Huvos. It could be proven with larger sample of patients. Bacci et al, showed that risk of recurrence increased with increasing SAP, inadequate surgical margin and poor response to neoadjuvant chemotherapy.,23,24 SAP had been used to monitor bone malignancy in which the level increased in bone forming tumor. However SAP level also increased in liver metastases. More spesific indicator was bone specific alkaline phosphatase (BSAP), but still not available in our center. ${ }^{24}$

\section{Metastases}

Lung metastases developed in five patients (25\%), all of them also had local recurrence. All of five died $(\mathrm{p}=0.000)$. This result similar with previous studies. More than $90 \%$ of patients with osteosarcoma with lung metastases died even when ablative procedure had been performed. Most of cases had had micrometastases before diagnosis was established. Risk factors for metastases were inadequate excision, poor response to neoadjuvant chemotherapy (Huvos I, II) and inadequate adjuvant chemotherapy. ${ }^{22}$

Five-year metastases-free survival was $57.13 \pm 10.04 \%$. The result was not different from other studies $(70 \%){ }^{22}$ There was no significant correlation between metastases and patient's characteristics ( $p>0.05)$. Kaplan-Meier curve formed by tumor size and type of Huvos had constant pattern. Patients with tumor size $<10 \mathrm{~cm}$ and good type of Huvos always had better metastasis free survival.

Tumor size, increased level of SAP dan Huvos could be predictive factors that influenced survival, local recurrence and metastases.

\section{Complications}

We evaluated infections, graft fracture, bone resorption, limb shortening, joint instability and complication caused by side effect of chemotherapy. Several operative procedures had been performed to overcome these conditions. Infection occurred in five patients $(20 \%)$. Amputation was performed in two of three patients that also developed local recurrence. One patient had partial skin necrosis and was managed by debridement and local flap. Two of five underwent debridement and one of them used Ilizarov technique for bone transport. They were relieved from infections. One of five that had proximal humerus tumor also developed bone resorption and was planned for further procedure using allograft. Infections 
could be minimized by proper pre-operative planning, adequate antibiotic and good handling in operative procedure. A study from Davidson AW et al, reported $4 \%$ bone resorption occurred at proximal humerus. It could be caused by far revascularization distance. ${ }^{5}$

Two patients had graft fracture caused by falling. Then performed revision ORIF (open reduction internal fixation) with bone graft/cement and immobilized by casting. Chen $\mathrm{TH}$ et al. reported $20 \%$ graft fracture occurred in ECI combined $15 \%$ in allograft. ${ }^{25}$

Limb shortening developed in one patient who was operated at 12 years of age. Although the epiphyseal plate had been preserved, 2-cm shortening occurred. Patient used additional sole to overcome the problem. Futani et al. reported $17.5 \%$ immature patients underwent ECI had shortening $\geq 2 \mathrm{~cm} \cdot{ }^{15}$

Knee instability always occurred in patients with tumor around the knee. This condition could be tolerated by patients and did not interfere with daily activity. In other studies it was also reported that knee instability developed in most cases of tumor around the knee. ${ }^{2}$

One patient had another complication caused by side effect of adjuvant chemotherapy (leucopenia). Deaths following chemotherapy administration have been reported by some studies. But there was still not enough evidence that the death was caused by chemotherapy. ${ }^{2}$

\section{Union Time}

Union occurred in fifteen of twenty patients with union time rate of 8.13 months (4-12 months). This was not too different with previous report (6-8 months), with full weight bearing in month $12 . .^{4,25}$ Remodelling was very limited and suggested that exchange by vital bone would not occur. There was always part of dead bone and fibrous tissue. ${ }^{2,5,25}$

\section{MSTS score}

All patients with no evidence of disease (NED) had good MSTS score rate (70.63\%). This result was similar with other studies $(68 \%)$. Patients with complications had poor score rate $(41.63 \%)$, combined with $57 \%$ in other studies. ${ }^{5}{ }^{26}$ Functional score was significantly correlated with local recurrence $(\mathrm{p}=0.025)$, metastases $(\mathrm{p}=0.011)$, complication $(\mathrm{p}=0.03)$, combinations with local recurrence + metastases $(\mathrm{p}=0.000)$ (Table 3$)$. Functional result in patients with NED also depended on rehabilitation program postoperatively.

It can be concluded that the outcomes of 20 stage IIB osteosarcoma patients treated by ECI in our center were good. The procedure could be useful alternative of limb salvage procedure in treating stage IIB osteosarcoma regarding limitation of endoprosthesis and allograft. Tumor size, SAP level, and type of Huvos could be perdictive factors that influenced prognosis in osteosarcoma stage IIB treated by ECI. This study should be continued with larger sample to have a statistically significant result.

\section{REFERENCES}

1. Salter RB. Neoplasm of musculoskeletal tissues. In: Textbook of disorders and injuries of musculoskeletal system. $3^{\text {rd }}$ ed. Philadelphia: Lippincott-Williams-Wilkins, 1999; p. 400-3.

2. Bacci G, Ferrari S, Lari S, Mercuri M, Donati D, Longhi A, et al. Osteosarcoma of the limb : amputation or limb salvage in patients treated by neoadjuvant chemotherapy. $\mathrm{J}$ Bone Joint Surg (Br). 2002;84-B:88-92.

3. Foukas AF, Deshmukh NS, Grimer RJ, Mangham DC, Mangos EG, Taylor S. Stage-IIB osteosarcomas around the knee : A study of MMP-9 in surviving tumour cells. J Bone Joint Surg [Br]. 2002;84-B:706-11.

4. Uyttendaele D, De Schryver A, Claessens H, Roels H, Berkvens P, Mondelaers W. Limb conservation in primary bone tumours by resection, extracorporeal irrradiation, and re-implantation. J Bone Joint Surg (Br). 1988;70-B:348-53.

5. Futani H, Minamizaki T, NishimotoY, Abe S, Yabe H, Ueda T. Long-term follow up after limb salvage in skeletally immature children with a primary malignant tumor of the distal femur. J Bone Joint Surg Am. 2006;88A:595-603.

6. Aksnes LH, Bauer HCF, Jebsen NL, Follerås G, Allert C,Haugen GS, et al. Limb-sparing surgery preserves more function than amputation : A Scandinavian sarcoma group study of 118 patients. J Bone Joint Surg [Br]. 2008;90-B:786-94.

7. Hatano H, Ogose A, Hotta T, Endo N, Umezu H, Morita T. Extracorporeal irradiated autogenous osteochondral graft : A histological study. J Bone Joint Surg [Br]. 2005;87-B.1006-11.

8. Raymond AK, Ayala AG, Knuutila S. Conventional osteosarcoma. In: World health organization classification of tumours of soft tissue and bone. $1^{\text {st }}$ ed. Lyon: IARC Press, 2002; p. 264-85.

9. Unni KK. Osteosarcoma. In : Dahlin's bone tumors general aspects and data on 11,087 cases. $5^{\text {th }}$ ed. Philadelphia: Lippincott-Raven Publishers, 1996; p. 143-96.

10. Gupta A, Meswania J, Pollock R, Cannon SR, Briggs TWR, Taylor S, et al. Non-invasive distal femoral expandable endoprosthesis for limb-salvage surgery in paediatric tumours. J Bone Joint Surg [Br]. 2006;88-B:649-54.

11. Krieg AH, Mani M, Speth BM, Stalley PD. Extracorporeal irradiation for pelvic reconstruction in Ewing's sarcoma. J Bone Joint Surg [Br]. 2009;91-B:395-400.

12. Jeon DG, Kim MK, Cho WH, Song WS, Lee SY. Pasteurized autograft-prosthesis composite for reconstruction of proximal tibia in 13 sarcoma patients. J Surg Oncol. 2007. Available from: http//www.interscience.wiley.com.

13. Huang TL, Chen TH,Chen WY, Chen WM, Liu CL, Lo WH. Allograft arthrodesis of the knee in high-grade osteosarcoma. J Chin Med Assoc. 2005;68:425-30.

14. Shalaby S, Shalaby H, Bassiony A. Limb salvage for osteosarcoma of the distal tibia with resection arthrodesis, autogenous fibular graft and Ilizarov external fixator. J Bone Joint Surg [Br]. 2006;88-B:1642-6.

15. Chen TH, Chen WM, Huang CK. Reconstruction after intercallary resection of malignant bone tumor: comparison 
between segmental allograft and extracorporeally irradiated autograft. J Bone Joint Surg (Br). 2005;87-B: 704-9.

16. McDonald DJ. Limb-salvage surgery for treatment of sarcomas of the extremities. Am J Roentgenol. 1994;163:509-13.

17. Davies NM, Stalley PD. Extracorporeal irradiation and its role in the treatment of primary pelvic bone tumours. J Bone Joint Surg Am. 2003;85.

18. Davidson AW, Hong A, McCarthy SW, Stalley PD. En-bloc resection, extracorporeal irradiation, and reimplantation in limb salvage for bony malignancies. J Bone Joint Surg (Br). 2005;87-B:851-7.

19. Ham J, Koops HS, Veth RP, van Horn JR, Molenaar WR, Hoekstra HJ. Limb salvage surgery for primary bone sarcoma of the lower extremities: long-term consequences of endoprosthetic reconstructions. Ann Surg Oncol. 1998;5:423-36.

20. Kager L, Zoubec A, Pootschger U, Kastner U, Flege S, Kempf-Bielack B, et al. Primary metastatic osteosarcoma: presentation and outcome of patients treated on neoadjuvant cooperative osteosarcoma study group protocols. J Clin Oncol. 2003;21:2011-8.

21. Unni KK, Inward CY, Bridge JA. Bone tumor. In: Tumors of the Bones and Joints. 4th ed. Silver Spring: ARP Press, 2005; p. 135-92.
22. Bacci G, Longhi A, Versari M,Mercuri M, Bricolli A,Picci P. Prognostic factors for osteosarcoma of the extremity treated by neoadjuvant chemotherapy: 15 years experience in 789 patients treated at a single institution. Cancer. 2006;106:1154-61.

23. Ward WG, Mikaelian K, Mirra Js. Pulmonary metastases of stage IIB extremity osteosarcoma and subsequent pulmonary metastases. J Clin Oncol. 2004;12:1849-58

24. Bielack SS, Kempf-Bielack B, Delling G,Exner GU,Flege $\mathrm{S}$, Helmke $\mathrm{K}$ et al. Prognostic factors in high-grade osteosarcoma of the extremities or trunk: An analysis of 1,702 patients treated on neoadjuvant cooperative osteosarcoma study group grotocols. J Clin Oncol. 2002;20:776-90.

25. Ward WG, Mikaelian K, Mirra Js. Functional and oncological outcome after limb salvage surgery for sarcoma of the upper limb. J Bone Joint Surg Am. 2006;88

26. Krieg AH, Davidson AH, Stalley PD. Intercalary femoral reconstruction with extracorporeal irradiated autogenous bone graft in limb salvage procedure. J Bone Joint Surg (Br). 2007;89-B:366-71. 